\title{
Territorial and environmental management in the indigenous lands of Paru de Leste river: a collective challenge in the northern Brazilian Amazon
}

\author{
Gestão territorial e ambiental nas terras indígenas do \\ Rio Paru de Leste: um desafio coletivo no Norte da \\ Amazônia brasileira
}

Iori van Velthem Linke

Cecília Awaeko Apalai ${ }^{\text {b }}$

Ima Célia Guimarães Vieirac

Roberto Araújo Santos Jr. ${ }^{d}$

${ }^{a}$ Doutor em Ciências Ambientais, Fundação Nacional do Índio - Funai, Santaém, PA, Brasil. End. Eletrônico: linke.iori@gmail.com

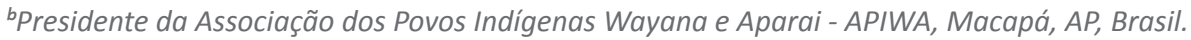
End. Eletrônico: ceciliaawaeko@gmail.com

'Doutora em Ecologia, Museu Paraense Emilio Goeldi, Belém, PA, Brasil. End.Eletrônico: ima@museu-goeldi.br

${ }^{d}$ Doutor em Etnologia, Museu Paraense Emilio Goeldi, Belém, PA, Brasil End. Eletrônico: araujo.roberto808@gmail;.com

doi:10.18472/SustDeb.v11n1.2020.19804

\section{ABSTRACT}

The National Policy for Environmental and Territorial Management of Indigenous Reserves - (PNGATI in Portuguese) aims to promote quality of life in a sustainable way for indigenous peoples in their lands, respecting socio-cultural autonomy and their own forms of territoriality. This text shows and discusses its socio-political reach and mobilization involved in the implementation of PNGATI with the indigenous peoples of the Paru de Leste River, northern Amazon. Data were collected during the construction stages and execution of the Territorial and Environmental Management Plan through 2014 to 2018. The data suggest that despite some permanent implementation challenges, the management plan was built in order to respect the constitutional precepts of autonomy and collective well-being, empowering, within the limits of this public policy, the indigenous peoples of the region. 
Keywords: PNGATI. Amazon. Paru de Leste. Wayana. Aparai.

\section{RESUMO}

A Política Nacional de Gestão Ambiental e Territorial - PNGATI objetiva promover a qualidade de vida de forma sustentável aos povos indígenas em suas terras, respeitando a autonomia sociocultural e suas próprias formas de territorialidade. Discute-se nessas linhas seu alcance sociopolítico e mobilização envolvidas na implementação da PNGATI com os povos indígenas do rio Paru de Leste, norte da Amazônia. Dados foram levantados durante as etapas de construção execução do Plano de Gestão Territorial e Ambiental, de 2014 a 2018. Os resultados sugerem que, apesar de alguns desafios permanentes de implementação, o plano de gestão foi construído de forma a respeitar os preceitos constitucionais da autonomia e bem-estar coletivo, empoderando, dentro dos limites da política pública, os povos indígenas da região.

Palavras-Chave: PNGATI. Amazônia. Paru de Leste. Wayana. Aparai.

\section{INTRODUCTION}

Indigenous rights in Brazil, before 1988, had as their foundation and objective the guarantee the integration process of the indigenous people into the national society, or even its suppression, as occurred in several cases to make room for national economic and territorial expansion projects (CUNHA, 1987; 1992; RIOS, 2002; HEMMING, 2009; BANIWA, 2012). Until then national indigenous agencies, such as the Indian Protection Service (in portuguese: SPI), succeeded by the National Indian Foundation (FUNAI), had the mission of providing the indigenous people with assistance, always from the relative indigenous incapacity perspective, with a tutelar view of their territories and livelihoods, as the indigenous and indigenist history asserts (OLIVEIRA, 2002; 2008; OLIVEIRA; FREIRE, 2006; CUNHA, 2009; LISBOA, 2017; GRUPIONI; OLIVEIRA; LINKE, 2018; ARAÚJO; SILVA; HERNÁNDEZ, 2019).

The Brazilian Federal Constitution approved in 1988 changed the course of this story though. As seen in Chapter VIII on the caput of its initial article number 231 the rupture with the past surpassing the tutelage and the assimilationist assumption, opened way for legitimation and recognition of sociocultural difference societal autonomy of indigenous peoples in Brazil, guaranteeing their original rights over the territory, according to their present and future collective projects (RIOS, 2002; BANIWA; CUNHA; DUPRAT; 2012).

Thus, the Indigenous Lands (IL, in portuguese "Terra Indígena": $\mathrm{TI}$ ) came about which are administratively delimited areas whose objective is to serve as a material and symbolic substrate for the exclusive and inalienable enjoyment of a determined people (or ethnic collective), so that they can live with autonomy and self-determination in their own forms of "physical and cultural reproduction", "according to their uses, customs and traditions" (CUNHA, 2009; 2013; BANIWA, 2012; DUPRAT, 2012; CUNHA; BARBOSA, 2018). Autonomy and determination were further strengthened when Brazil became a signatory to Indigenous and Tribal People 169 Convention of the International Labor Organization (ORGANIZAÇÃO DAS NAÇÕES UNIDAS, 1989), (RIOS, 2002; BANIWA; DUPRAT; 2012).

However, the physical delimitation of space in closed polygons watertighted areas with finite and limited natural resources, forcing indigenous peoples to appropriate a new paradigm of territoriality with direct implications on traditional ways of life, cultural and physical reproduction as mentioned in the Federal Constitution (CUNHA, 2009; COMANDULLI, 2012; INGLÊS-DE-SOUZA; ALMEIDA, 2012; ARAÚJO; SILVA; HERNÁNDÉZ, 2019).

As Little (2002) points out, the native territoriality needed to be revised, since the demarcation of indigenous lands brought the physical discontinuities of the lived territory to the heart of the villages 
(LITTLE, 2002). Therefore the transfigured territory had to be relearned, reoccupied and reidentified (LITTLE, 2002; OLIVEIRA, 2002, 2008; ARAÚJO; SILVA; HERNANDÉZ, 2019). From this point on, urgent questions regarding the guarantee of survival and physical and cultural reproduction, customs and continent traditions of a geographical space delimited over time became urgent.

In order to get this issue solved in 2012 the National Policy for Environmental and Territorial Management of Indigenous Lands (in Portuguese PNGATI: Política Nacional de Gestão Ambiental e Territorial de Terras Indígenas) (Presidential Decree no 7.747 June 5th, 2012) (COMANDULLI, 2012; INGLÊS-DE-SOUZA, 2012; INGLÊS-DE-SOUZA; ALMEIDA, 2012; FUNAI, 2013).

Evidently indigenous peoples already lived and managed their territories in their own ways, which are considered low impact activities, seasonal related, where there are specific eating habits, territorial use and occupation and classification systems of different beings and representations for space and time. (POSEY 1997a; 1997b; 2002; VELTHEM, 2003; LIMA; POZZOBON, 2005; SMITH; ALMEIDA, 2012; BALÉE, 1994; 2013).

It is argued that one of the greatest achievements of PNGATI was to bring a regulatory framework state to the constitutional guarantees of indigenous peoples, reiterating the right to exclusive usufruct of their traditionally occupied lands, while striving to ensure that such demarcated territories correspond to the needs and specificities of each indigenous people (INGLÊS-DE-SOUZA, 2012; ARAÚJO; SILVA; HERNÁNDEZ, 2019).

To this end, the Decree provides two instruments for the local application. In its Article 2 is written "the ethnomapping and ethno-zoning are tools for the territorial and environmental management" (PNGATI, 2012, Article 2). According to FUNAI's guidelines (FUNAI, 2013), these two instruments aim to generate mobilization and systematize information and knowledge within an intercultural dialogue in order to support discussions in collective management forums, which can be organized and synthesized in a territorial and environmental management plan (in Portuguese: Plano de Gestão Territorial e Ambiental - PGTA, also known as "Life Plans" or "Action Plans" in Brazil) (APIO, 2012; APINA; AWATAC; IEPÉ, 2017).

It is observed that PNGATI has the potential to take the State's relations with indigenous peoples to another level. It is important to know what kind and nature of social empowerment the application of this policy reflects within the indigenous communities. Measuring the "empowerment", however, is not a simple task, considering the multiple meanings that this term may have (FREIRE, 1981, 1987; LABONTE, 1994; SAITO, 2002; BARQUERO, 2012; DOMICIANO, 2012). The social empowerment, as pointed out by Labonte, can be constructed and understood from two verbal forms, the transitive and the intransitive (LABONTE, 1994). In the first case, empowerment involves a subject that acts on an object by the donation of power from an entity to third parties, necessarily within limits that are given (LABONTE, 1994; MEIRELLES; INGRASSIA, 2006; BARQUERO, 2012). The second case involves the subject's own action on himself (LABONTE, 1994; BARQUERO, 2012).

Within a Freirean perspective, it is possible to analyze the local application of PNGATI by adapting the conception worked by Barquero (2005), where the application the PNGATI, as a caudatory policy of the Federal Constitution of 1988 really solidifies the indigenous tutelage break, triggering "a process of social action in which individuals take possession of their own lives through interaction with other individuals, generating critical thinking in relation to reality, favoring the construction of personal and social capacity and enabling transformation social power relations", or not (BARQUERO, 2005, p. 76).

In order to contribute to this discussion, this article aims to present and discuss a PGTA framework, in this specific case the plan of the indigenous peoples that inhabit the high and medium course of the Paru de Leste River, northern Pará. 


\section{METHODOLOGICAL ROUTE}

\subsection{THE INDIGENOUS PEOPLES OF PARU DE LESTE RIVER}

The Wayana, Aparai, Tiriyó, Akuriyó, Txikiyana among others people are speakers of Karib languages and live immemorially in the triple border area of Suriname, French Guiana and Brazil in peaceful communion established through relationship networks, commercial and interethnic marriage, including some Tupi peoples (VELTHEM, 2003; BARBOSA, 2004; GALLOIS; GRUPIONI, 2009; GRUPIONI; OLIVEIRA; LINKE, 2018).

In Brazil, they currently number around 1,100 people from 220 family nuclei, scattered through 24 villages located on the banks of the high and medium course of the Paru de Leste River, in northern Pará (GRUPIONI; OLIVEIRA; LINKE, 2018).

Their territory is concentrated in the eastern portion of the "Tumucumaque Complex", also known as "Paru de Leste region", being composed by two contiguous lands: Terra Indígena (IL, in Portuguese: TI) Parque do Tumucumaque and TI Rio Paru D'Este (Figure 1). Both areas were approved by Presidential Decree in November 3rd of 1997, and the total area surpass 4.2 million hectares containing different Amazonian vegetation types (VELTHEM, 2003; GRUPIONI, 2010; VELTHEM; LINKE, 2010, 2014a).

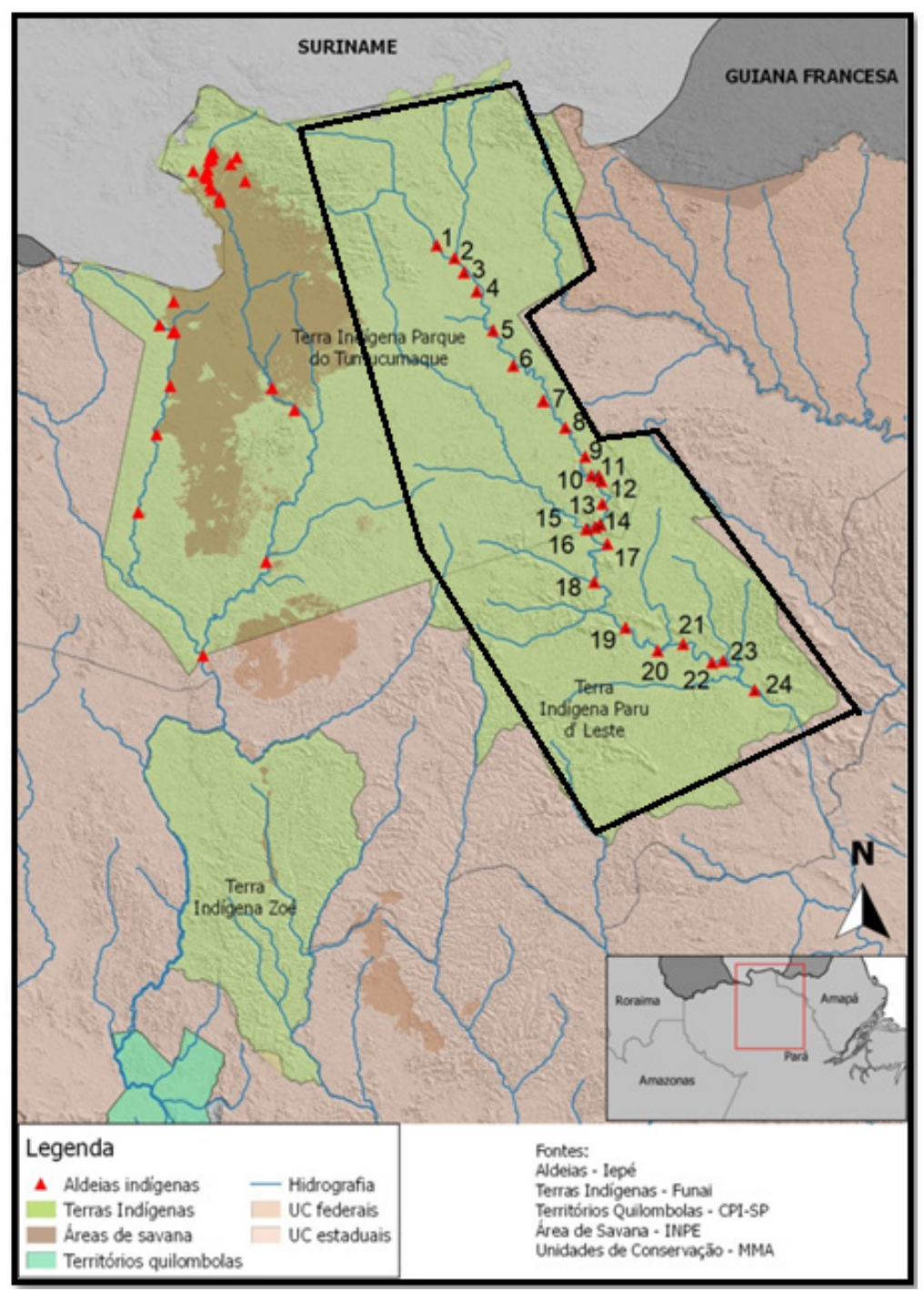

Figure 1 | Map of the Indigenous Lands Parque do Tumucumaque and Rio Paru D'Este. Polygon in black: channel of the Paru de Leste river, the area covered by the Paru de Leste PGTA. 
Table 1 | List of indigenous villages on the Paru de Leste river channel.

\begin{tabular}{|c|c|c|}
\hline Village map $n$. & Name & $\begin{array}{c}\text { Estimated population } \\
\text { (2018) }\end{array}$ \\
\hline 1 & Pakupinan & 16 \\
\hline 2 & Cachoeirinha & 33 \\
\hline 3 & Mataware & 110 \\
\hline 4 & Taunumai & 13 \\
\hline 5 & Jahelai & 43 \\
\hline 6 & Manau & 16 \\
\hline 7 & Tyryryman & 14 \\
\hline 8 & Iliwa & 11 \\
\hline 9 & Maxipurimo & 33 \\
\hline 10 & Bona & 288 \\
\hline 11 & Murei & 21 \\
\hline 12 & Kurieukuru & 21 \\
\hline 13 & Aramapuku & 20 \\
\hline 14 & Arawaka & 37 \\
\hline 15 & Tapauku & 54 \\
\hline 16 & Sitale Kumnta & 12 \\
\hline 17 & Kurupohpano & 38 \\
\hline 18 & Xuixuimene & 74 \\
\hline 19 & Jolokoman & 20 \\
\hline 20 & Ananapiare & 36 \\
\hline 21 & Kurumurihpano & 37 \\
\hline 22 & Itapeky & 25 \\
\hline 23 & Pururé & 60 \\
\hline 24 & Parapara & 46 \\
\hline
\end{tabular}

Source: Authors, 2019.

Their productive activities are based on swidden crop systems where great agrobiodiversity is cultivated with an emphasis on bitter cassava (Manihot esculenta Crantz). The hunting activity is concentrated in the winter season (from January to August), while fishing is in the summer (from August to January), the forest gathering is done all year long (GRUPIONI; GALLOIS, 2009; VELTHEM; LINKE, 2010; 2014a; LINKE; VELTHEM, 2017; GRUPIONI; OLIVEIRA; LINKE, 2018).

In the last hundred years, these people have undergone a series of external interventions that transfigured territorial areas and therefore their forms of settlement in physical space (LAPOINTE, 1970; SCHOEPF, 1972; GALLOIS, 1986; VELTHEM, 2003; BARBOSA, 2004; GRUPIONI, 2010; LINKE; VELTHEM, 2017).

After the promulgation of the Brazilian Federal Constitution in 1988, the lands of Paru de Leste people have regularized bringing to the communities public policies developed by the Special Secretariat for Indigenous Health (Portuguese: Secretaria Especial de Saúde Indígena: SESAI), Formal education by the Indigenous Nucleus in the Education Secretariat of the Amapá (Portuguese: NEI / SEED-AP), and the local monitoring held by the national indigenous foundation (Portuguese: Fundação Nacional do Índio: FUNAI), all with bureaus located in Macapá in Amapá State (GALLOIS; GRUPIONNI, 2009; LINKE; VELTHEM, 2017; GRUPIONI; OLIVEIRA; LINKE, 2018). 
In order to monitor these policies and organizing the regional indigenous mobilization and representation, a first association was created in 1996, the Association of Indigenous Peoples of Tumucumaque (Portuguese: APITU). This was dismembered years later in two associations: in 2009 the Association of Indigenous Peoples Tiriyó, Katxuyana and Txikyana (Portuguese: APITIKATXI), to serve the people concentrated in the western region of the Tumucumaque Complex and, in 2010, in the Association of Indigenous Peoples Wayana and Apalai (Portuguese: APIWA), which, despite its name, represents the entire eastern portion, including peoples of other ethnicities (GRUPIONI; OLIVEIRA; LINKE, 2018).

The traditional indigenous leadership is played by the adult and elder men, especially those responsible for founding a village. Today, the leadership condition is more fluid, with an increasing participation of women and young people, notably the indigenous teachers and Indigenous Health Agents (Portuguese: AIS), all with a large participation in the APIWA affairs and the local forums and assemblies (GRUPIONI; OLIVEIRA; LINKE, 2018).

\subsection{DOCUMENTAL AND FIELD RESEARCH}

The data were collected during fourteen PGTA construction and execution workshops held in the Paru de Leste River region, carried out between 2014 and 2019, totaling a sampling effort of more than 100 days. Information was obtained from participant observation, informal conversations and semistructured interviews, following guidelines and methods enshrined in the ethnographic literature (BALÉE, 1994, 2013; POSEY, 1997a; BEGOSSI et al., 2002; CAMPOS, 2002; ALBUQUERQUE; LUCENA; CABALZAR, 2010; CUNHA, 2010; VIERTLER, 2002).

The semi-structured interview sought to discuss knowledge and practices about the environment, the history of territorial occupation and census surveys; counting on destined spaces to note manifestations on local problematic experiences, as well as ideas and suggestions of resolutions, many of which were integrated to the PGTA.

In September 2014 three collective workshops were held with a one-week duration each. The first took place in the Xuixuimene village (TI Rio Paru D'Este), a second in the Matawaré village and a third in the Bona village (both in TI Parque do Tumucumaque). In the first workshop, semi-structured interviews were conducted with eight leaders from the eight villages present in the middle course of the Paru de Leste River (inside the TI Rio Paru d'Este).

In the second workshop, interviews were conducted with six representatives from the six villages on the upper Paru de Leste River (TI Parque do Tumucumaque). In the third workshop, 10 leaders from the 10 villages in the middle of the river were interviewed, concluding all 24 villages existing in the region (of the two IL). A few months later, in Bona village all he 24 leaders met again in order to discuss and validate the whole process.

Thus, from 2015 to 2019 we moved to the PGTA execution phase, where the rest of the information was collected, especially during seven indigenous researchers training modules with a one-week duration each.

This research was approved by the indigenous leaders in two moments: 1) Paru de Leste River ordinary leaders assembly, promoted by APIWA, FUNAI and Instituto lepé, which took place in November 2014, and 2) an extraordinary assembly in February 2019. Both have written records. 


\section{HISTORY OF CONSTRUCTION OF THE TERRITORIAL AND ENVIRONMENTAL MANAGEMENT PLAN}

In the Paru de Leste region, many territorial and environmental management experiences, such as natural resource management, cultural enhancement actions, territorial protection activities, school booklets production, links with surrounding protected areas, were carried out even before the PNGATI publication, etc. (VELTHEM; LINKE, 2010; 2014b, 2014c; LINKE; VELTHEM, 2017; GRUPIONI; OLIVEIRA; LINKE, 2018).

All of these experiences were accumulated in the villages, being periodically revisited in subsequent meetings and assemblies, included in the final PGTA discussion and construction. It is important to searchk such history to understand the taken paths and the options made over time (see box 2 below).

Table 2 | Historical picture of the main actions for the environmental and territorial management of Paru de Leste region.

\begin{tabular}{|c|c|c|c|}
\hline Data & Actions & Participanting Public & Results and innovations \\
\hline $\begin{array}{l}2005 \\
\text { to } \\
2008\end{array}$ & $\begin{array}{l}\text { Cultural valorization } \\
\text { workshops }\end{array}$ & $\begin{array}{l}\text { Five workshops of a one-week each, with } \\
\text { the participation of all indigenous leaders. } \\
\text { Total audience of more than } 300 \text { people } \\
\text { (men, women, adults and children). }\end{array}$ & $\begin{array}{l}\text { Beginning of discussions on } \\
\text { material and immaterial cultural } \\
\text { heritage. Discussion for handling } \\
\text { raw materials needs used in } \\
\text { traditional objects. Publications. }\end{array}$ \\
\hline $\begin{array}{l}2007 \\
\text { to } \\
2008\end{array}$ & $\begin{array}{l}\text { Socio-environmental } \\
\text { survey workshops. }\end{array}$ & $\begin{array}{l}\text { Five workshops and two meetings with } \\
\text { the presence of indigenous leaders } \\
\text { from all villages. Survey of the main } \\
\text { socio-environmental problems in the } \\
\text { communities. }\end{array}$ & $\begin{array}{l}\text { Survey of the main } \\
\text { socio-environmental problems } \\
\text { in the communities. Beginning } \\
\text { of discussions of collective } \\
\text { land management. }\end{array}$ \\
\hline $\begin{array}{l}2008 \\
\text { to } \\
2009\end{array}$ & $\begin{array}{l}\text { Experimental game and } \\
\text { fishing survey done } \\
\text { in ancient villages }\end{array}$ & $\begin{array}{l}\text { Five workshops in Bona, Murei and } \\
\text { Maxipurimo villages. Target audience: about } \\
300 \text { people. Inventory, survey and diagnosis } \\
\text { of hunting and fishing done in the region. }\end{array}$ & $\begin{array}{l}\text { Beginning of debates on } \\
\text { management of shared hunting } \\
\text { and fishing territories. }\end{array}$ \\
\hline $\begin{array}{l}2009 \\
\text { to } \\
2015\end{array}$ & $\begin{array}{l}\text { Wayana and Aparai } \\
\text { research training. }\end{array}$ & $\begin{array}{l}\text { Fourteen one-week workshops for } 15 \text { young } \\
\text { Wayana and Aparai (women and men) from } \\
\text { eight different villages. }\end{array}$ & $\begin{array}{l}\text { Instrumentalization of the } \\
\text { youth in documentation and } \\
\text { cultural research forms on } \\
\text { native livelihood in their own } \\
\text { languages. The results are } \\
\text { discussed at APIWA assemblies. }\end{array}$ \\
\hline 2012 & $\begin{array}{l}\text { PNGATI Decree } \\
\text { No. } 7,747 \text { of June } 5 \text { th, } \\
2012 \text { published }\end{array}$ & Indigenous lands declared by FUNAI & PNGATI Institution. \\
\hline $\begin{array}{l}2014 \\
\text { to } \\
2015\end{array}$ & $\begin{array}{l}\text { Socioenvironmental } \\
\text { Diagnosis }\end{array}$ & $\begin{array}{l}\text { Three regional workshops } \\
\text { (check methodology) }\end{array}$ & $\begin{array}{l}\text { General diagnosis, including } \\
\text { information on previous actions } \\
\text { and activities. PGTA's first version. }\end{array}$ \\
\hline $\begin{array}{l}2016 \\
\text { to } \\
2018\end{array}$ & PGTA execution project & $\begin{array}{l}\text { Agreements and actions foreseen in the } \\
\text { plan are carried out involving all villages. }\end{array}$ & $\begin{array}{l}\text { Paru de Leste PGTA } \\
\text { starts to run. }\end{array}$ \\
\hline
\end{tabular}

Source: Authors, 2019. 
The PGTA organization process itself begins in 2014 (see methodology). At this time, there was close monitoring of the leaders, APIWA's directors, FUNAI and lepé Institute technicians in all stages (figure 2). In possession of the collected and organized information, in late 2014 a large indigenous assembly was held in Bona village when the diagnosis results were presented, discussed, rectified and validated by all. In addition to the problems raised, and in many reiterated points, possible strategies and solutions were presented and discussed, which many became agreements between that forum participants, including the participation of each institution according to their competencies (APIWA, FUNAI, lepé), and community members (leaders, AIS, indigenous teachers). Once this stage was completed, a first edition of the PGTA was considered done. Subsequently, these data were refined and published in book format (GRUPIONI; OLIVEIRA; LINKE, 2018).

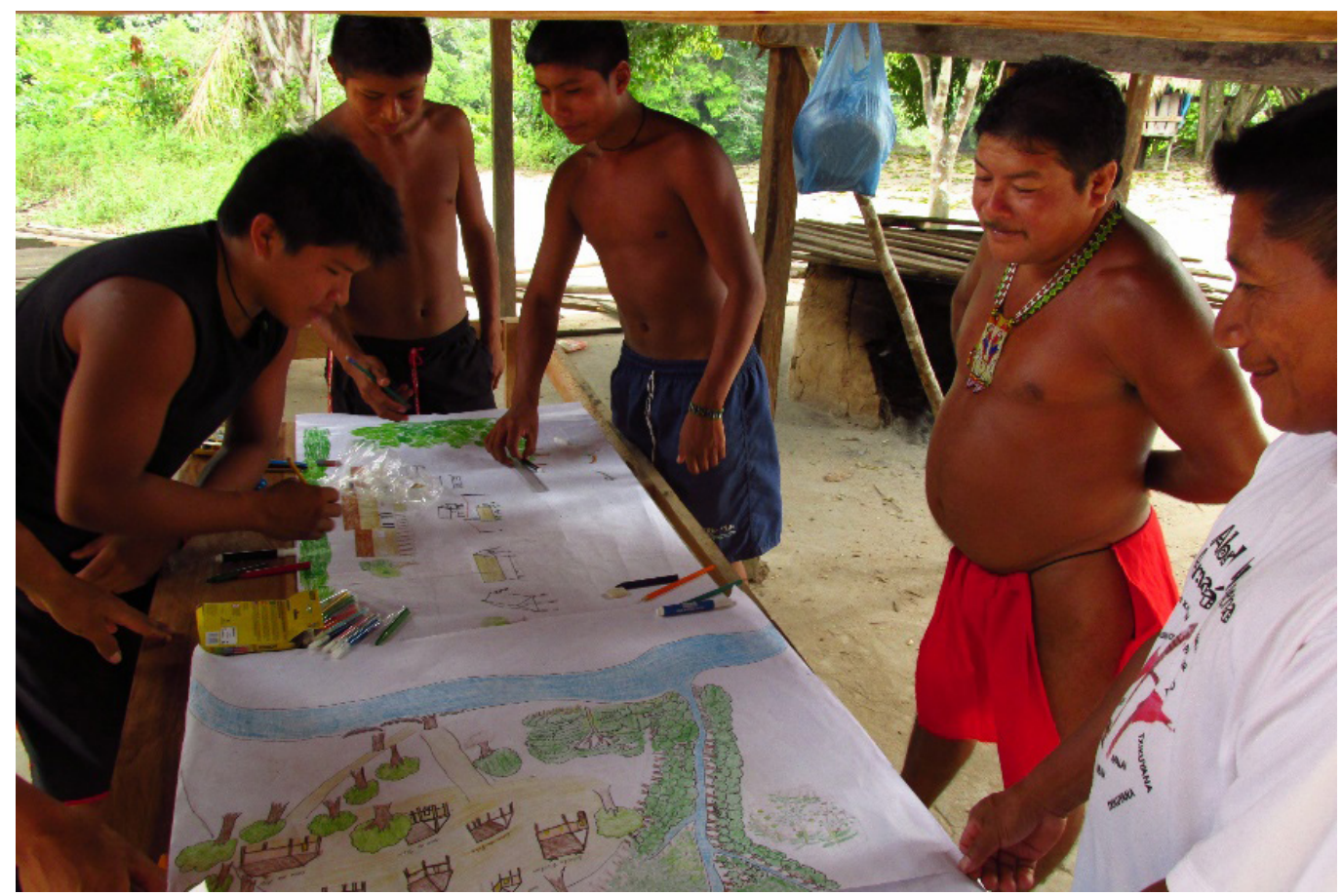

Figure 2 | Socio-environmental diagnosis workshop on Bona village, 2014.

Source: LINKE, 2014.

For historical, geographical and, mainly, sociocultural reasons, the indigenous leaders of the Tumucumaque Complex decided to organize their PGTA in two components, following the dichotomy present in the indigenous organizations: i) western portion (APITIKATXI); ii) eastern portion (APIWA), which is representative of the 24 villages on the Paru de Leste River: as know as the "Paru de Leste PGTA".

Although there are many points in common, there is no political preponderance nor overlap between the sides. Central issues, such as health, are dealt with jointly. For more local issues, such as resource management, there is independence in the decisions made and in the execution of activities.

\section{THE PARU DE LESTE PGTA AND THE PNGATI}

The Paru de Leste PGTA was organized by the indigenous leaders in six thematic axes inspired by precursor plans, much exemplified in the discussions, such as the Life Plan of the Indigenous Peoples of Oiapoque and the Kaxinawá and Ashaninka Indigenous Land PGTA of the Breu River (APIO, 2009; GAVAZZI, 2007). The axes seek to encompass dimensions that go beyond environmental and territorial management, namely: 1) Territorial Protection; 2) Governance and Empowerment; 3) Management and sustainable use of natural resources; 4) Culture; 5) School education and 6) Health. 
Following FUNAI guidelines, the PGTA was built to be cyclical to facilitate future revisions during the process, with the following steps: 1) mobilization, 2) discussion of problems and agreements / possible solutions, 3) activity planning, 4) execution of activities, 5) results monitoring and appreciation, returning to the starting point (FUNAI, 2013).

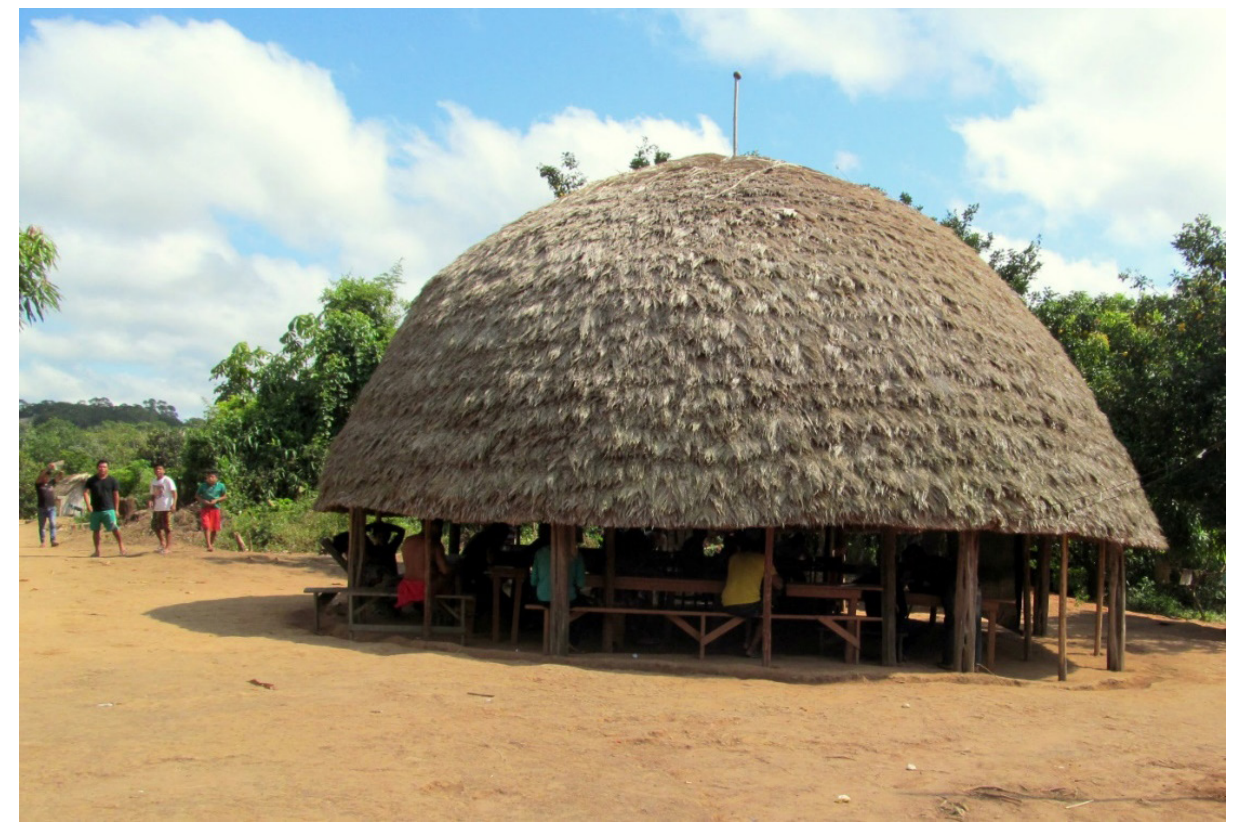

Figure 3 | A PGTA meeting held inside the Maxipurimo's communal house.

Source: LINKE, 2018.

Table 3 shows in a summarized format the Rio Paru de Leste PGTA based on its constitutive axes, including the objectives, problems and the main strategies and solutions agreed by the indigenous leaders. For all axes the actors directly involved are the communities, the APIWA, FUNAI, and the lepé Institute. For more details, check the PGTA publication (GRUPIONI; OLIVEIRA; LINKE, 2018).

Table 3 | Paru de Leste PGTA summarized.

\begin{tabular}{|c|l|l|l|}
\hline & Objectives & Problems & Strategies \\
\hline $\begin{array}{c}\text { 1) TERRITORIAL } \\
\text { PROTECTION }\end{array}$ & $\begin{array}{l}\text { To guarantee the } \\
\text { physical integrity } \\
\text { of indigenous } \\
\text { lands. }\end{array}$ & $\begin{array}{l}\text { - Ostensibly occupy the limits with new } \\
\text { villages and surveillance bases; } \\
\text { villages are areas at risk } \\
\text { of invasion. }\end{array}$ & $\begin{array}{l}\text { Constant surveillance and monitoring } \\
\text { actions, including competent bodies; } \\
\text { - Communication system; } \\
\text { - Regularize landing strips; }\end{array}$ \\
\hline 2) GOVERNANCE AND & $\begin{array}{l}\text { Strengthen the } \\
\text { PGTA decision } \\
\text { and deliberation } \\
\text { bodies. }\end{array}$ & $\begin{array}{l}\text { Qualify the appropriate waste disposal. } \\
\text { participation and } \\
\text { social control of } \\
\text { traditional leaders and } \\
\text { the representative } \\
\text { association face } \\
\text { incoming new } \\
\text { challenges }\end{array}$ & $\begin{array}{l}\text { - Qualify and strengthen indigenous leaders } \\
\text { and the association to monitor the PGTA and } \\
\text { other indigenous policies; } \\
\text { - Build local plan for free, prior and informed } \\
\text { consultation; } \\
\text { - Exchanges visits with other peoples; } \\
\text { - Articulate with surrounding protected areas; }\end{array}$ \\
\hline
\end{tabular}




\begin{tabular}{|c|c|c|c|}
\hline & Objectives & Problems & Strategies \\
\hline $\begin{array}{l}\text { 3) MANAGEMENT AND } \\
\text { SUSTAINABLE USE }\end{array}$ & $\begin{array}{l}\text { Guarantee } \\
\text { stocks of natural } \\
\text { resources for } \\
\text { the survival and } \\
\text { sovereignty of } \\
\text { the population }\end{array}$ & $\begin{array}{l}\text { Loss of agrobiodiversity } \\
\text { in fields and villages } \\
\text { patios. Increasing } \\
\text { scarcity of hunting, } \\
\text { fishing and some raw } \\
\text { materials. }\end{array}$ & $\begin{array}{l}\text { - Promote intercultural dialogues on natural } \\
\text { resource management; } \\
\text { - Strengthen the exchange of native seedlings } \\
\text { and seeds; } \\
\text { - Locally observe climate change; } \\
\text { - Zoning "savings" areas free from hunting, } \\
\text { fishing, gathering and agriculture activities. } \\
\text { - Do not bring or use genetically modified } \\
\text { seeds or pesticides in IL. }\end{array}$ \\
\hline 4) CULTURE & $\begin{array}{l}\text { Ensure a strong } \\
\text { and active } \\
\text { culture, walking } \\
\text { together with } \\
\text { external cultural } \\
\text { elements. }\end{array}$ & $\begin{array}{l}\text { Discontinuity and } \\
\text { disinterest in traditional } \\
\text { knowledge and its } \\
\text { forms of transfer. }\end{array}$ & $\begin{array}{l}\text { - Promote cultural events; } \\
\text { - Search for ways to reconnect the transfer of } \\
\text { intergenerational knowledge; } \\
\text { - Produce cultural materials for internal and } \\
\text { external circulation (books, videos, etc.) } \\
\text { - Training of youth. } \\
\text { - Registration of cultural heritage. }\end{array}$ \\
\hline 5) EDUCATION & $\begin{array}{l}\text { Ensure } \\
\text { differentiated } \\
\text { and quality } \\
\text { school } \\
\text { education, } \\
\text { which serves } \\
\text { for life inside } \\
\text { and outside the } \\
\text { villages. }\end{array}$ & $\begin{array}{l}\text { Absence of political- } \\
\text { pedagogical program } \\
\text { (PPP) for the region. } \\
\text { Poor infrastructure, few } \\
\text { indigenous teachers, } \\
\text { non-indigenous } \\
\text { professionals who are } \\
\text { poorly qualified and / } \\
\text { or discouraged. }\end{array}$ & $\begin{array}{l}\text { - Creation of PPP for the region with wide } \\
\text { indigenous participation; } \\
\text { - Creation of local school calendar; } \\
\text { - Lunch with local foods; } \\
\text { - Production of differentiated material; } \\
\text { - Improve infrastructure; } \\
\text { - Training of indigenous and non-indigenous } \\
\text { teachers. } \\
\text { - Qualify the monitoring of the local leaders. }\end{array}$ \\
\hline 6) HEALTH CARE & $\begin{array}{l}\text { Ensure } \\
\text { quality and } \\
\text { contextualized } \\
\text { medical care, } \\
\text { focused on } \\
\text { prevention. }\end{array}$ & $\begin{array}{l}\text { Poor infrastructure; } \\
\text { few indigenous and } \\
\text { non-indigenous } \\
\text { health professionals } \\
\text { to the demand; lack } \\
\text { of medicines in the } \\
\text { villages. }\end{array}$ & $\begin{array}{l}\text { - Improve infrastructure; } \\
\text { - Training of Indigenous Health Agents; } \\
\text { - Regularize the health professional schedules; } \\
\text { - Qualify the monitoring of the local leaders. }\end{array}$ \\
\hline
\end{tabular}

Source: Adapted from GRUPIONI; OLIVEIRA; LINKE, 2018).

\section{TERRITORIAL MANAGEMENT AND THE SOCIO-POLITICAL REACH OF PNGATI IN PARU DE LESTE}

The Paru de Leste PGTA presents a series of challenges linked by various issues of different natures, such as the area remote access, regional high socio-cultural diversity, intergenerational issues, consumption of manufactured products and settlements established outside traditional standards (GRUPIONI; OLIVEIRA; LINKE, 2018).

Each PGTA carries the aspirations and priorities of its people, within unique histories and mobilization processes (COMANDULLI; INGLÊS-DE-SOUZA; ALMEIDA, 2012). This, however, does not prevent analogies and intersection points. The PGTA of the Xingu Indigenous Park (PIX), in Mato Grosso, for example, allocates a large part of its efforts to the territorial protection of the Xingu springs that were left out of bounds and today drain vast pastures and huge soy crops (ATIX; ISA, 2016).

Territorial boudaries are also addressed in the Paru de Leste PGTA, but in a different way, as the territorial contexts are not the same. The strategy is based on the review and occupation of indigenous lands vulnerable points, through the opening of villages and monitoring bases, associated with articulated 
expeditions involving the communities and official organizations, an effective communication system, and landstrips regularization. Additionally, handles proper waste disposal. Such strategies are interesting, as they mean the cartographic limits incorporation into the native logic (GUIMARÃES, 2014). This can be faced as political resistance and rights guarantee act, mainly to live in peace in their own land.

Regarding territorial protection, the PGTA the Wajãpi in Amapá, provides strategies with the surroundings that are populated by rural settlements, besides, aims to strengthen traditional Wajãpi mobility (APINA; AWATAC; IEPÉ, 2017). However, many parallels are found between the Wajãpi and Paru de Leste PGTAs, as both belong to the indigenous movement historically linked to Macapá, where decentralized state units are located, and partners organizations, such as lepé which operate in both regions (GALLOIS; GRUPIONI, 2009; GRUPIONI; KAHN, 2013; APINA; AWATAC; IEPÉ, 2017).

Thus, perhaps the central point that links both PGTAs is the constant search for strengthening internal governance, through the qualification and legitimation of local leadership and their associations, involving the construction of many political bridges, such as those that deal with management beyond limits and the youth training (APINA; AWATAC; IEPÉ, 2017; GRUPIONI; OLIVEIRA; LINKE, 2018).

Therefore, this axis is fundamental and transversal, since, in the Freirean sense of empowerment, it is only with qualified participation, transposing the historical power by alienation that it will be possible fulfill the achievement of the public policies, such as PNGATI and others, like those linked in the health and school education axes (FREIRE, 1987; BARQUERO, 2012).

The youth formation mentioned is also the flagship of other PGTAs, such as those of the TI Kaxinawa of Rio Humaitá and TI Mamoadate, both in Acre. In such plans there is the figure of the "indigenous agroforestry agent" as key players in intercultural dialogue, appearing on all of their plan axes (GAVAZZI; ROCHA 2015; ALMEIDA; OCHOA; GAVAZZI, 2016). It also occurs in Paru de Leste, where the training empowerment instrument to the knowledge and epistemological systems dialogue, internal and external to the communities, collaborating and connecting all axes (LINKE; VELTHEM, 2017; GRUPIONI; OLIVEIRA; LINKE, 2018).

The PGTA the Indigenous Lands of northwest Negro River also focuses on the intercultural dialogue of research, combining outside knowledge and techniques with traditional knowledge forms (FOIRN; ISA, 2017, 2018). Among several, we can mention as successful the experiences of fisheries management, started years ago, in the Negro River tributaries Tiquié and Içana (CABALZAR, 2005; 2010).

Similarly, the axis of management and sustainable use of natural resources focuses on the productive systems of the peoples of the Paru de Leste River, adopting measures that mix traditional forms with adaptations of rural extension techniques, within a knowledge dialogue. This point is also observed in the PGTA of TI Kaxinawá and Ashaninka of the Breu River, in Acre, with ethno-zoning tools and rules for the use of the environment (GAVAZZI, 2007).

We see, therefore, that PNGATI brought to the Paru de Leste River a great mobilizing potential by allowing people not only to know indigenous policies, but also the possibility to collectively think and organize the territory, identities, and interfaces with the outside world (LITTLE, 2002; GALLOIS, 2004).

Although the data indicate that the Paru de Leste PGTA construction was anchored in the wide and historical participation of the locals, we believe it is premature to judge the degree of social empowerment given by the local development of the PNGATI. It is clear, on the other hand, that the creative processes of the plan objectively sought to naturalize and internalize concerns about life in physically limited territories, opening up different possibilities. Among the successes, the process enabled the indigenous people to think critically of the current political moment, to raise awareness about threats to their rights and discuss mobilization strategies. It is not by chance that there is a specific axis for governance and local empowerment. This critical look, of self-recognition, taking possession of the real, as Freire said, was catalyzed by the local implementation of PNGATI, and the PGTA can be understood as a corollary of the process started in 1997, when indigenous lands were regularized (FREIRE, 1981; 1987). 
But when we return to the authors who celebrate Freire's criticism, Horochovski and Meirelles, for instance, claim that the intransitive aspect of empowerment brings visibility, influence and capacity for action and decision to the communities and organizations involved (HOROCHOVSKI; MEIRELLES, 2007). This, however, according to Barquero, would demand a detachment, an emancipation of civil society (in this case, the indigenous people as a whole) from the State, being, in this hypothetical case, the PGTA a space for the emancipation of the excluded ones: the indigenous people (BARQUERO, 2012). As seen, PNGATI has mechanisms in its wording that seek more symmetrical dialogues, overcoming the tutelary paradigm. Following the line of some authors, this is undoubtedly a form of intransitive empowerment, as it is possible to conclude that with PNGATI the indigenous peoples of Brazil gain influence and control over their lives in their territories (WALLERSTEIN; BERSTEIN, 1994; INGLÊS-DE-SOUZA, 2012).

On the other hand, we cannot avoid remembering that PNGATI remains a state policy, organized within a bureaucratic framework that is alien to indigenous communities, constituting a challenge also for the responsible technical body (GUIMARÃES, 2014). Besides, PNGATI focuses on at least declared indigenous lands, which ultimately remain Union lands, as clearly stated in Article 231 of the Federal Constitution. Although the application of PNGATI is not an imposition, it ends up being in practice since it centralizes all the actions of "territorial and environmental management in indigenous lands" given in the State X indigenous peoples interface. At this point, it is necessary to remember that indigenous lands safeguard large territorial extensions, being fundamental components in strategies for environmental conservation in Brazil, especially in the Amazon (SANTILLI, 2005; FERREIRA; VENTICINQUE; ALMEIDA, 2007; NOLTE et al. 2013; CRISOSTOMO et. Al., 2015; BONANOMI et al. 2019).

Regarding the traditional livelihood forms identified as drivers of such conservation, it is necessary to return to the initial question of the Rousseauian "good savage" since we must ask the indigenous if placing so much responsibility on their shoulders would not be, as Cunha points out, a great misunderstood, "(...) a case of western projection of ecological concerns about a good savage ad hoc built?" (CUNHA, 2009, p. 277).

Thus, by limiting and framing the political action area, it is possible to conclude that PNGATI can also represent a transitive form of organizational empowerment for indigenous peoples, including those on the Paru de Leste River (BARQUERO, 2012).

\section{FINAL CONSIDERATIONS}

PNGATI is a very recent policy in the historical framework of relations between the national state and indigenous peoples in Brazil. It proposes to change paradigms that have long been ingrained, such as tutelary leading. Thus, doubts regarding the effects and natures of this policy development within the communities will take some time to be fully understood by all the involved actors, indigenous or not. That is why, as we have seen, it is possible to today view PNGATI in such different ways.

On the issue of empowerment, PNGATI may reach different spectra depending on the context of its local implementation. PGTAs represent different forms of local empowerment, depending on many factors that sometimes go beyond community dynamics and the interfaces given with external agents and partners. The history of the people and the territory in question weighs heavily in the assessment.

In the case of the Paru de Leste PGTA the data and records show that the arrival of PNGATI led to a more acute critical eye, a reflection that generated mobilizations.

Its PGTA, as we see in the tables, basically points out ways to seek improvements in living conditions in the villages, seeking to create bridges between the actions of indigenous leaders, state agencies and civil society partners. Besides, the PGTA aims at strengthening internal and external policy, premises internalized in an axis with this specific objective. Such an end indicates a real path for local empowerment through the internal and external mobilization and social control strengthening, instrumentalizing the indigenous people for the execution of PNGATI and other public policies. 
There is always work to be done, and this being a recent and under construction policy, there is still a lot of room for improvement. In the PGTA observed, there are still many outstanding issues, mainly those related to the future functioning of the different actors involved in the planning, execution, monitoring and evaluation of the proposed actions and arrangements. Also, problems that have not yet been identified may arise in the course of implementing the plan, and it is plausible that previously priority issues cease to be them in the course of the process.

We must not lose sight of the fact that concepts of "life quality" and "well-being" in indigenous lands, practically PNGATI premises, are equally susceptible to internal transformations and reframing in the time flow. And these transformations are fit for evaluations that, ultimately, belong only to the interested indigenous people. In any case, monitoring mechanisms for the continuous improvement of the plan's functioning are provided for in the PGTA, following FUNAI guidelines.

Finally, these and other issues that are intended to measure degrees of ownership need to be continuously monitored and studied. Given the high degree of dynamism and complexity of this subject, future studies on the themes of this text are very welcome. We hope that this first look at the Paru de Leste PGTA will contribute to this process.

\section{REFERENCES}

albuberque, U. P. de, LUCENA, R. F. P.; CUNHA, L. V. F. C., Métodos e Técnicas na Pesquisa Etnobiológica e Etnoecológica. Recife: NUPEEA. 2010. 560p.

ALMEIDA, M. I.; OCHOA, M. L. P; GAVAZZI, R. Terra nossa mãe nunca se acaba: Plano de Gestão da Terra Indígena Mamoadate. Rio Branco, CPI-AC. P. 137p. 2016.

APINA, AWATAC; IEPÉ. Plano de Gestão Socioambiental Terra Indígena Wajãpi. Macapá, Instituto lepé. 2017.

APIO. Plano de vida dos povos e organizações indígenas do Oiapoque. Oiapoque, APIO. 85 p. 2009

ARAÚJO, A.; SILVA, E. H.; HERNÁNDEZ, D. G. O contexto pós-demarcatório: quando se trata de redefinir o controle social sobre os recursos naturais e bens culturais. Espaço Ameríndio, Porto Alegre, v. 13, n. 1, p. 218-252, jan./jun. 2019.

ATIX; ISA, Plano de Gestão do Território Indígena do Xingu. São Paulo, Instituto Socioambiental. 2016.

BALÉE, W. Footprints of the Forest: Ka'apor Ethnobotany: the Historical Ecology of Plant Utilization by an Amazonian People. New York: Columbia University Press. 1994. 396p.

BALÉE, W. Cultural Forests of the Amazon: A Historical Ecology of People and their Landscapes. Tuscaloosa: University of Alabama Press. 2013. 268 p.

BANIWA, G. A conquista da cidadania indígena e o fantasma da tutela no Brasil conPGTAorâneo. (in): RAMOS, A. R. Constituições Nacionais e Povos Indígenas. Belo Horizonte: Editora Humanitas. p. 206 - 227, 2012

BARBOSA, G.C. Das trocas de bens. In: GALLOIS, D. Redes de relações nas Guianas. São Paulo: Associação editorial Humanitas: Fapesp, p. $59-111,2004$

BAQUERO, R. V. A. Empoderamento: questões conceituais e metodológicas. Revista Debates. Núcleo de Pesquisas sobre a América Latina/UFRGS. Porto Alegre: Vol. 1, n 1, dez. 2005.

BARQUERO, R. V. A. Empoderamento: instrumento de emancipação social? - Uma discussão conceitual. Revista Debates, a situação das Américas: Democracia, Capital Social e Empoderamento, Porto Alegre, v. 6, n. 1, p.173187, jan.-abr. 2012.

BEGOSSI, A; HANAZAKI, N.; SILVANO, R. A. M. Ecologia humana, etnoecologia e conservação, in: AMOROZO, M. C. M.; MING, L. C. ; SILVA, S. M. (eds.) Métodos de coleta e análise de dados em etnobiologia, etnoecologia e disciplinas correlatas. Rio Claro: EdUNESP. 2002. Pp. 93-128. 
BONANOMI, J.; TORTATO, F. R.; GOMES, R. S. R.; PENHA, J. M. P.; SALDANHA., A. B.; PERES, C. - Protecting forests at the expense of native grasslands: Land-use policy encourages open-habitat loss in the Brazilian cerrado biome, Perspectives in Ecology and Conservation (17), p. 26-31. 2019.

BRASIL. Constituição Federal da República Federativa do Brasil. 1988

BRASIL. Política Nacional de Gestão Ambiental e Territorial de Terras Indígenas - PNGATI. Decreto Presidencial no 7.747 de 05 de junho de 2012.

CABALZAR, A. (Org.) Peixe e Gente no Alto Rio Tiquié: conhecimentos tukano e tuyuka em ictiologia, etnologia. São Paulo, Instituto Socioambiental. 2005.

CABAlZAR, A. (Org.) Manejo do Mundo: Conhecimentos e Práticas dos Povos Indígenas do Rio Negro. São Paulo, Instituto Socioambiental. 2010

CAMPOS, M. D. Etnociência ou etnogafia de saberes, técnicas e práticas? in:AMOROZO, M. C. M.; MING, L. C. ; SILVA, S. M. (eds.) Métodos de coleta e análise de dados em etnobiologia, etnoecologia e disciplinas correlatas. Rio Claro: EdUNESP. p. 47-92,2002.

COMANDULLI, C. S. Gestão Ambiental e Territorial de Terras Indígenas: fazendo planos. Ruris, Campinas. Volume 10 (1). Pp. 41-71, 2012.

CRISOSTOMO, C A., ALENCAR, A., MESQUITA, I, SILVA, C. I., DOURADO, F. M., MOUTINHO, P., CONSTANTINO, P. ; PIONTEKOWSKI, V. Indigenous Lands in the Brazilian Amazon: carbon stocks and barriers to deforestation. 2015

CUNHA, M. M. C. Os Direitos do Índio: ensaios e documentos. São Paulo: Editora Brasiliense. 1987.

CUNHA, M. M. C. Introdução A uma história indígena. (in.) CUNHA, M. M. C. História dos Índios no Brasil. São Paulo, Companhia das Letras. 1992. Pp. 9-24.

CUNHA, M. M. C. Cultura com Aspas e outros ensaios. São Paulo: Cosac Naiyf. 2009. 436p.

CUNHA, M. M. C. Índios no Brasil: História, direitos e cidadania. São Paulo: Claro Enigma. 2012.

CUNHA, M. M. C.; BARBOSA, S. (orgs.) Direitos dos Povos Indígenas em disputa. São Paulo: Editora UNESP. 2018. 367p

DOMICIANO, C. S. O capital social e a educação ambiental como elementos catalisadores de empoderamento em comunidades. Rev. eletrônica Mestr. Educ. Ambient. ISSN 1517-1256, v. 28, janeiro a junho de 2012

DUPRAT, D. O Estado pluriétnico, in: Antonio Carlos de Souza Lima e Maria Barroso-Hoffmann: Além da Tutela: Bases para uma nova política indigenista III. Rio de Janeiro: Contracapa editora. 2002. P. 41-47

DUPRAT, D. O direito sob o marco da plurietnicidade/multiculturalidade. In: RAMOS, A. R. Constituições Nacionais e Povos Indígenas. Belo Horizonte: Editora Humanitas. p. 228 - 236, 2012.

FERREIRA, L. V.; VENTICINQUE, E.; ALMEIDA, S. O desmatamento na Amazônia e a importância das áreas protegidas. Estudos Avançados, 19 (53), p. 157-166, 2005.

FOIRN; ISA. Governança e Bem Viver Indígena: PGTAs das Terras Indígenas do Alto e Médio Rio Negro Volume 3. 2017. 38 p.

FOIRN; ISA. Governança e Bem Viver Indígena: PGTAs das Terras Indígenas do Alto e Médio Rio Negro Volume 4. 2018. 36 p.

FREIRE, P. Pedagogia do oprimido. Rio de Janeiro: Paz e Terra, 1981.

FREIRE, P. Ação cultural para a libertação e outros escritos. Rio de Janeiro: Paz e Terra, 1987.

FUNDAÇÃO NACIONAL DO ÍNDIO. Planos de Gestão Territorial e Ambiental de Terras Indígenas: Orientações para Elaboração. Brasília: FUNAI. 2013. 
GALLOIS, D. T. Terras ocupadas? Territórios? Territorialidades? in: RICARDO, F. (Ed.) Terras indígenas e unidades de conservação da natureza: o desafio das sobreposições. São Paulo, Instituto Socioambiental, p. 37 - 41, 2004.

GALLOIS, D. T; GRUPIONI, D. F. Povos Indígenas no Amapá e Norte do Pará: Quem são, onde estão, quantos são, como vivem e o que pensam? São Paulo: Instituto lepé de Pesquisa e Formação Indígena. 2a ed. 2009.

GAVAZZI, R. A. Plano de Gestão Territorial e Ambiental da Terra Indígena Kaxinawá e Ashaninka do rio Breu. Rio Branco, Comissão Pró-Índio do Acre. 2007.

GAVAZZI, R.; ROCHA, M. C. Plano de Gestão Territorial e Ambiental da Terra Indígena Kaxinawá do Rio Humaitá, Rio Branco, CPI/AC. 142p. 2015

GRUPIONI, M. D. F. Dispersão e Sedentarismo nas TIs Tumucumaque e Paru D’Este. In: RICARDO, R.; RICARDO, F. (Eds.) Povos indígenas no Brasil: 2006 - 2010. São Paulo, Instituto Socioambiental, p. 321 - 323, 2010

GRUPIONI, L. D. B.; KAHN, M. Gestão Territorial e Ambiental em terras indígenas na Amazoia brasileira: os percursos da Rede de Cooperação Alternativa. São Paulo, Instituto lepé. 2013.

GRUPIONI, M. D. F.; OLIVEIRA, C. S.; LINKE, I. L. Plano de Gestão das Terras Indígenas Parque do Tumucumaque e Rio Paru d’Este. São Paulo: Instituto lepé. 2018. 156p.

GUIMARÃES, V. M; B. Política nacional de gestão territorial e ambiental de terras indígenas (PNGATI): a busca pela autonomia ambiental e territorial das terras indígenas no Brasil. National. Revista Direito Ambiental e sociedade, v. 4, n. 1, 2014 (p. 157-177)

HOROCHOVSKI, R. R.; MEIRELLES, G. Problematizando o conceito de empoderamento. In: Seminário Nacional Movimentos Sociais, Participação e Democracia. Florianópolis, 2., 2007.

HEMMING, J. Fronteira Amazônica: A Derrota dos Índios Brasileiros. São Paulo: Edusp; 2009. 712p

INGLÊS-DE-SOUSA, C. N. Gestão Territorial, conceitos fundamentais in: INGLÊS-DE-SOUSA, C. ; ALMEIDA, F. V. R. de (orgs.). Gestão Territorial em Terras Indígenas no Brasil. Brasília: Ministério da Educação. p. 30 - 79, 2012.

INGLÊS-DE-SOUSA, C. N.. ; ALMEIDA, F. V. R. de (orgs.). Gestão Territorial em Terras Indígenas no Brasil. Brasília: Ministério da Educação. p.1 - 268, 2012.

INSTITUTO BRASILEIRO DE GEOGRAFIA ESTATÍSTICA - IBGE. Censo demográfico brasileiro: 2010: Características Gerais dos Indígenas - Resultados do Universo. 2010.

LABONTE, R.H. Promotion and empowerment: reflections on professional practice. Health Education Quarterly, New York, v. 21, p. 253-268, 1994.

LAPOINTE, J. 1970. Residence patterns and Wayana social organization. 162 p. Ph.D. Thesis. (Social Science). Columbia University, Estados Unidos da América. Não publicado.

LIMA, D.; POZZOBON, J. Amazônia Socioambiental: Sustentabilidade Ecológica e Diversidade Social. Estudos Avançados, 19 (54), p. 55-76, 2005.

LINKE, I.L.; VELTHEM, L. H. V. V. O livro da cerâmica. São Paulo: Instituto lepé. 2017.

LISBOA, J. F. K. Brasília, Revista sobre acesso à justiça e direitos nas américas, vol. 1, no001, pp: 1-17, 2017.

LITTLE, P. Territórios Sociais e Povos Tradicionais no Brasil: Por uma antropologia da territorialidade. Universidade de Brasília (UNB): Série Antropologia no322. 2002. 01-32p.

MEIRELLES, M; INGRASSIA, T. Perspectivas téoricas acerca do empoderamento de classe social. Revista Eletrônica "Fórum Paulo Freire" Ano 2 № 2 Agosto 2006

NOLTE C.; AGRAWAL A., SILVIUS K. M.; SOARES-FILHO B.S. Governance regime and location influence avoided deforestation success of protected areas in the brazilian amazon. Proc. Natl. Acad. Sci. Usa, 110, 4956-4961. 2013 
OLIVEIRA, J. P. Cidadania e Globalização: povos indígenas e agências multilaterais. In: LIMA A. C. S.; BARROSOHOFFMANN, M. Etnodesenvolvimento e políticas públicas: bases para uma nova política indigenista III. Rio de Janeiro: Editora Contracapa. p. 105 - 119, 2002.

OLIVEIRA, J. P. Sem a tutela, uma nova moldura de nação. In: OLIVEN, R.; RIDENTI, M.; BRANDÃO, G. (orgs.). 20 anos da Constituição Federal de 1988. São Paulo: ANPOCS/Hucitec, 2008. p. 251-275.

OLIVEIRA, J. P.; FREIRE, C. A. R., A presença Indígena na Formação do Brasil. Brasília: Ministério da Educação. 2006. 265p

ORGANIZAÇÃO DAS NAÇÕES UNIDAS. Convenção no 169 sobre os povos indígenas e tribais. 1989

POSEY, D. A. Introdução - Etnobiologia: teoria e Prática. in: RIBEIRO, B. (Coord.) Suma etnológica brasileira: I etnobiologia. EDUFPA, BELÉM. p. 1 - 15, 1997a.

POSEY, D. A. Manejo da floresta secundária, capoeiras, campos e cerrados (kayapó) in: RIBEIRO, B. (Coord.) Suma etnológica brasileira: I etnobiologia. EDUFPA, BELÉM.p. 199-213, 1997b.

POSEY, D. A. Kayapó Ethnoecology and culture. Londres: Routledge. 2002, 304p

RIOS, A. V. Terras Indígenas no Brasil: definição, reconhecimento e novas formas de aquisição. in: LIMA, A. C. S. ; BARROSO-HOFFMANN, M. (Orgs.). Além da Tutela: Bases para uma nova política indigenista III. Rio de Janeiro: Contra-capa livraria. p. $63-81.2002$.

SAITO, C. H. Política nacional de educação ambiental e construção da cidadania: desafios conPGTAorâneos. In: RUCHEINSKY, A. et al. Educação ambiental: abordagens múltiplas. Porto Alegre: Artmed, 2002.

SANTILLI, J. Agrobiodiversidade e os diretos dos agricultores. São Paulo: Peirópolis, 2009.310 p.

SCHOEPF, D. Historique et situation actuelle des indiens Wayana- Aparai du Brésil. Bulletin Annuel Du Museum d’Ethnographie de Geneve, 14: p. 15-64. 1972.

SMITH, M.; ALMEIDA, F. V. R. de. Dimensão ambiental. in: INGLEZ DE SOUSA, C. ; ALMEIDA, F. V. R. de (orgs.). Gestão Territorial em Terras Indígenas no Brasil. Brasília: Ministério da Educação. p. 154-182. 2012.

VELTHEM, L. H. O belo é a fera: A estética de produção e da predação entre os Wayana. Lisboa, Assírio Alvim. 2003.

VELTHEM, L. H.; LINKE, I. L. O livro da arte gráfica Wayana e Aparai. Rio de Janeiro: Museu do Índio. 2010.

VELTHEM, L. H. V.; LINKE, I. L. O livro do arumã. São Paulo: Instituto lepé. 2014a.

VELTHEM, L. H. V.; LINKE, I. L.(ORG.). Poetohti Amorepatoh Aparai Omiry Poko: Livro da Língua aparai. Rio de Janeiro. Museu do Índio, 2014b.

VELTHEM, L. H. V.; LINKE, I. L.(ORG.). Epatop Pampilan Wajana Omi Jao: Livro da Língua wajana. Rio de Janeiro. Museu do Índio, 2014c.

VIERTLER, R. B., Métodos Antropológicos como ferramenta pra estudo em etnobiologia e etnoecologia. in: AMOROZO, M. C. M.; MING, L. C. ; SILVA, S. M. (eds.) Métodos de coleta e análise de dados em etnobiologia, etnoecologia e disciplinas correlatas. Rio Claro: EduNESP,p. 11-29. 2002.

WALLERSTEIN, N. BERNSTEIN, E.. Introduction to community emporwerment, participation, education, and health. Health Education Quarterly: Special Issue Community Emporwerment, Participatory Education, and Health, parte I, v. 21, n. 2, p. 141-170, 1994. 